\title{
UJI EFEKTIVITAS PEMBERIAN EKSTRAK RIMPANG JAHE MERAH (Zingiber officinale var. Rubrum) SEBAGAI ANTIMIKROBA YANG BERSIFAT BAKTERISID TERHADAP BAKTERI Escherichia coli
}

\author{
Lisa Yuniati $^{1}$, Arina F Arifin ${ }^{2}$ dan Selly Silla Sakti ${ }^{3}$ \\ ${ }^{1}$ Bagian Kulit dan Kelamin Fakultas Kedokteran Universitas Muslim Indonesia Makassar \\ ${ }^{2}$ Bagian Histologi Fakultas Kedokteran Universitas Muslim Indonesia Makassar \\ ${ }^{3}$ Mahasiswa Pre Klinik Fakultas Kedokteran Universitas Muslim Indonesia Makassar
}

\begin{abstract}
Abstrak
Latar Belakang : Pada dasarnya Escherichia coli merupakan bakteri komensal saluran pencernaan. Namun, dapat menjadi patogen jika jumlah bakteri ini dalam saluran pencernaan meningkat atau berada di luar usus. Escherichia coli juga merupakan salah satu penyebab paling sering dari banyak infeksi bakteri umum. Resistensi Escherichia coli terhadap berbagai antibiotika telah banyak dilaporkan. Disisi lain, Indonesia merupakan salah satu negara yang kaya akan tanaman herbal yang sering digunakan sebagai salah satu upaya untuk menanggulangi masalah kesehatan. Salah satu tumbuhan yang digunakan adalah rimpang dari tumbuhan jahe merah (Zingiber officinale var. Rubrum). Metode Penelitian : Penelitian ini adalah penelitian true experimental post test melalui metode disc diffusion untuk menguji efektivitas pemberian ekstrak rimpang jahe merah (Zingiber officinale var. rubrum) sebagai antimikroba terhadap bakteri Escherichia coli. Hasil Penelitian : Dari konsentrasi 20\%, 40\%, 60\%, 80\%, dan 100\% ekstrak rimpang jahe merah terhadap bakteri Escherichia coli didapatkan bahwa pada konsentrasi $20 \%$ zona hambat yang terbentuk pada replikasi 1 dan 2 memiliki interpretasi intermediet. Pada konsentrasi $40 \%$ diameter zona hambat yang terbentuk pada replikasi 1 memiliki interpretasi intermediet sedangkan pada replikasi 2 memiliki zona hambat yang sensitif. Pada konsentrasi $60 \%$ memiliki zona hambat yang intermediet pada replikasi 1 sedangkan pada replikasi 2 memiliki zona hambat yang sensitif. Pada konsentrasi $80 \%$ terbentuk zona hambat yang sensitif pada kedua replikasi. Begitu pula pada konsentrasi $100 \%$ juga terbentuk zona hambat yang sensitif pada bakteri Escherichia coli pada kedua replikasi. Kesimpulan : Dari kelima konsentrasi rimpang jahe merah yang diujikan didapatkan hasil yang sensitif pada konsentrasi 40\%, 60\%, 80\% dan 100\%.
\end{abstract}

Kata Kunci : Esktrak Rimpang jahe merah (Zingiber officinale var. Rubrum), Escherichia coli 
PENDAHULUAN

Escherichia coli adalah salah satu bakteri basil gram negatif yang hidup secara tunggal atau berpasangan. ${ }^{1}$ Escherichia coli bersifat fakultatif anaerob dan banyak ditemukan dalam saluran pencernaan. Pada dasarnya Escherichia coli merupakan bakteri komensal saluran pencernaan. Namun, bakteri ini dapat menjadi patogen jika berada diluar saluran pencernaan. ${ }^{2}$

Menurut Dinas Kesehatan Kota Makassar, salah satu penyakit akibat infeksi bakteri Escherichia coli adalah diare. Diare sendiri masih menjadi masalah kesehatan masyarakat Kota Makassar. Kasus diare yang dilaporkan oleh 39 puskesmas se Kota Makassar sampai dengan desember 2013 sebanyak 28.908 kasus. Angka kesakitan (Incidence Rate/IR) penyakit diare pada tahun 2013 sebesar 21,3 per 1.000 penduduk, angka ini menurun dari tahun 2012 sebesar 21,6 per 1.000 penduduk dengan jumlah kasus 29.265. ${ }^{7}$

Disisi lain, Indonesia merupakan salah satu negara yang kaya akan tanaman herbal yang sering digunakan sebagai salah satu upaya untuk menanggulangi masalah kesehatan. Salah satu tumbuhan yang digunakan adalah rimpang dari tumbuhan jahe merah (Zingiber officinale var. Rubrum) yang merupakan salah satu dari temu-temuan suku Zingiberaceae. Rimpang jahe merah sudah digunakan sebagai obat secara turun-temurun karena mempunyai komponen volatile (minyak atsiri) dan non volatile (oleoresin) paling tinggi jika dibandingkan dengan jenis jahe yang lain. Rimpang jahe merah biasa digunakan sebagai obat masuk angin, gangguan pecernaan, sebagai analgesik, antipiretik, antiinflamasi, menurunkan kadar kolesterol, mencegah depresi, impotensi, dan lain-lain. ${ }^{9,10}$

Berangkat dari kepercayaan dan kebiasaan masyarakat Indonesia, serta masih kurangnya penelitian tentang pemanfaat tanaman-tanaman herbal ini terutama tanaman rimpang jahe merah (Zingiber officinale var. Rubrum), penulis tertarik ingin menguji efektivitas ekstrak rimpang jahe merah (Zingiber officinale var. rubrum) sebagai antimikroba bakterisid terhadap bakteri escherichia coli.

\section{METODE PENELITIAN}

Jenis penelitian ini penelitian true experimental post test melalui metode disc diffusion untuk menguji efektivitas pemberian ekstrak rimpang jahe merah (Zingiber officinale var. rubrum) sebagai antimikroba terhadap bakteri Escherichia coli.

Penelitian ini dilakukan di laboratorium Fakultas Farmasi UMI (laboratorium Fitokimia dan Mikrobiologi) dengan waktu penelitian mulai dari 30 April sampai dengan 31 Mei 2017.

Pengambilan sampel Jahe Merah dilakukan di Pasar Terong Kota Makassar. Dsiiapkan 5 buah vial yang berisi ekstrak jahe merah 20\%, 40\%, $60 \%, 80 \%$, dan $100 \%$. 
HASIL PENELITIAN

1. Zona Hambat Minimal Ekstrak Rimpang Jahe Merah terhadap bakteri Escherichia coli KONSENTRASI EKSTRAK RIMPANG JAHE VERAH

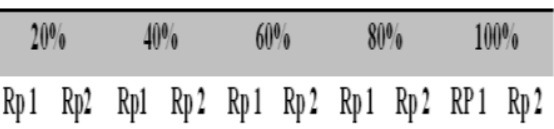

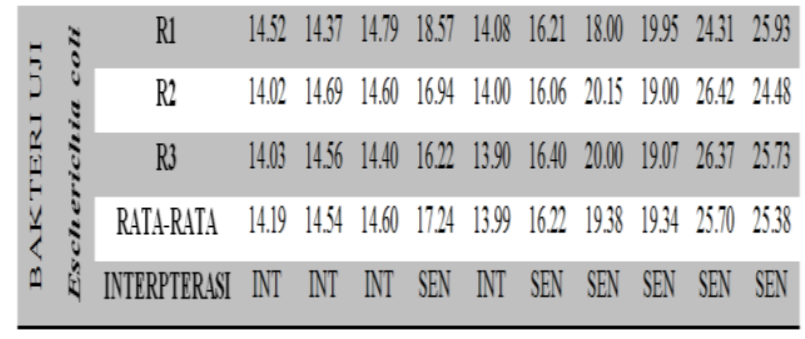

Keterangan Tabel :

$\mathrm{R} 1=$ Diameter 1

$\mathrm{R} 2=$ Diameter 2

R3 = Diameter 3

Rp1 = Replikasi/ pengulangan pertama Rp2 = Replikasi/ pengulangan kedua

Dari konsentrasi 20\%, 40\%, $60 \%$, 80\%, dan $100 \%$ untuk ekstrak rimpang jahe merah didapatkan bahwa pada konsentrasi $80 \%$ terbentuk zona hambat yang sensitif pada bakteri Escherichia coli pada kedua replikasi. Begitu pula pada konsentrasi 100\% juga terbentuk zona hambat yang sensitif pada bakteri Escherichia coli pada kedua replikasi.

2. Zona Hambat Minimal Ekstrak Kotrimokxazole terhadap bakteri Escherichia coli

\begin{tabular}{|c|c|c|c|c|}
\hline & & \multirow{3}{*}{ DIAMETER } & \multicolumn{2}{|c|}{ KONTROL POSITIF } \\
\hline & & & \multicolumn{2}{|c|}{ KOTRINOXAZOL } \\
\hline & & & Rp1 & Rp? \\
\hline \multirow{5}{*}{ 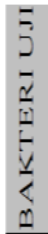 } & \multirow{5}{*}{$\begin{array}{l}5 \\
5 \\
5 \\
5 \\
5 \\
5 \\
0 \\
0\end{array}$} & R1 & 24.79 & 24.16 \\
\hline & & R2 & 24.11 & 24.57 \\
\hline & & R3 & 24.44 & 24.66 \\
\hline & & RATA-RATA & 24.45 & 24.46 \\
\hline & & INTERPTERASI & SENSITIF & SENSITIF \\
\hline
\end{tabular}

Pada kontrol positif dengan kotrimoxazol didapatkan zona hambat dengan interpretasi sensitif pada bakteri Escherichia coli pada kedua replikasi. Interpretasi zona hambat ditentukan berdasarkan acuan tabel interpretasi zona hambat, zona hambat $12 \mathrm{~mm}$ dikatakan resisten, 13-14 $\mathrm{mm}$ intermediate, dan $15 \mathrm{~mm}$ sensitif.

\section{PEMBAHASAN}

Rimpang jahe merah mengandung berbagai zat metabolit sekunder biologis aktif. Dalam rimpang jahe mengandung 1\%-4\% minyak atsiri dan oleoresin. ${ }^{13}$ Selain itu, rimpang jahe merah (Zingiber officinale var. Rubrum) juga mengandung zat pati sekitar $52,9 \%$ dan ekstrak yang larut dalam alkohol sekitar 9,93\%. ${ }^{16}$ Minyak atsiri pada rimpang jahe merah merah (Zingiber officinale var. Rubrum) memiliki kemampuan lebih besar dalam menghambat mikroba dibandingkan oleoresinnya. ${ }^{12}$ Berdasarkan penelitian yang dilakukan oleh Tita Rialita, dkk (2015) rimpang jahe merah segar mengandung 0,24\% kadar minyak esensial. ${ }^{14}$

Terbentuknya zona hambat mikroba oleh ekstrak segar rimpang jahe merah (Z. officinale var. Rubrum) dapat dilihat dari daerah bebas mikroba yang terbentuk di sekitar kertas cakram yang mengandung ekstrak segar rimpang jahe-jahean disebabkan karena adanya senyawa bioaktif yang terkandung didalam ekstrak. ${ }^{25}$

Konsentrasi 20\%, 40\%, 60\%, $80 \%$, dan $100 \%$ yang digunakan dalam 
penelitian ini menunjukkan perbedaaan luas zona hambat yang terbentuk. Pada konsentrasi $20 \%$ didapatkan hasil dengan interpretasi intermediet pada kedua replikasi. Pada replikasi 1 dengan konsentrasi $40 \%$ didapatkan zona hambat dengan interpretasi intermediet sedangkan pada replikasi 2 dengan konsentrasi yang sama didapatkan zona hambat dengan interpretasi sensitif. Pada replikasi 1 dengan konsentrasi $60 \%$ didapatkan zona hambat dengan interpretasi intermediet sedangkan pada replikasi 2 dengan konsentrasi yang sama didapatkan zona hambat dengan interpretasi sensitif. Pada konsentrasi $80 \%$ didapatkan zona hambat dengan interpretasi sensitif pada kedua replikasi. Dan pada konsentrasi 100\% juga didapatkan zona hambat dengan interpretasi sensitif pada kedua replikasi.

\section{KESIMPULAN}

Pada konsentrasi 40\%, 60\%, $80 \%$, dan $100 \%$ ekstrak rimpang jahe merah (Zingiber officinale var. Rubrum) didapatkan zona hambat yang sensitif terhadap bahkteri Escherichia coli.

\section{DAFTAR PUSTAKA}

1. Tarun Madappa. 2016. Escherichia coli Infection. America : Medscape

2. Agnes Roux, Christophe beloin, and Jean-Marc Ghigo. 2010. Escherichia coli biofilms. France : HAL Archives Ouvertes. PMCID : PMC2864707
3. Sri Agung. 2010. Escherichia coli (Makalah). Bandung : Fakultas Farmasi Universitas Padjajaran.

4. Febriy Firizki. 2013. Pola Kepekaan Escherichia Coli Dan Klebsiella Sp. Terhadap Antibiotik Sefalosporin Periode Tahun 2008-2012 Di Bandar Lampung (Skripsi). Lampung : Fakultas Kedokteran Lampung. ISSN 2337-3776

5. Citra Ayu, dkk. 2015. Gejala Penyerta Pada Balita Diare Dengan Infeksi Enteropathogenic Escherichia Coli (Epec) Di Puskesmas Rawat Inap Kota Pekanbaru JOM FK Volume 2 No. 1 Februari 2015. Pekanbaru

6. Midun. 2012. Uji Efektivitas Ekstrak Lengkuas Merah (Alpina purpurata K.Schum) Dalam Menghambat Pertumbuhan Bakteri Staphylococcus aureus dan Bakteri Escherichia coli dengan Metode Disc Diffusion. (Skripsi). Jakarta : Universitas Islam Negeri Syarif Hidayatullah Jakarta.

7. Andi Naisyah, dkk. 2014. Profil Kesehatan Kota Makassar 2013. Makassar : Dinas Kesehatan Kota Makassar.

8. Iga Prasetyo, dkk. 2015. Uji Kepekaan Bakteri Escherichia Coli O157:H7 Sapi Bali Asal Abiansemal - Badung - Bali Terhadap Antibiotik. Denpasar Bali : Indonesia Medicus Veterinus. 
9. Ester Natalia Panjaitan, dkk. 2012. Formulasi Gel Dari Ekstrak Rimpang Jahe Merah (Zingiber officinale Roscoe Vol. 1 (1): 9-20 (Jurnal). Sumatera Utara : Departemen Biologi Farmasi, Fakultas Farmasi Universitas Sumatera Utara 2 Departemen Teknologi Farmasi, Fakultas Farmasi Universitas Sumatera Utara.

10. Ilham Lexmana Azhari. 2014. Aktivitas Antimikroba Ekstrak Daun Kunyit (Curcuma Domestica Val.) Terhadap Escherichia Coli, Staphylococcus Aureus, Shigella Dysenteriae, Dan Lactobacillus Acidophilus 7140 (Tesis). Medan : Fakultas Pertanian Universitas Sumatera Utara.

11. Supriadi, dkk. 2011. Jahe (Zingiber officinale Rosc.). Bogor : Balai penelitian tanaman obat dan aromatic badan penelitian dan pengembangan pertanian pusat penelitian dan pengembangan pertanian kementrian pertanian. Hal 1,3,4,7.

12. Tita Rialita, dkk. 2015. Aktivitas Antimikroba Minyak Esensial Jahe Merah (Zingiber Officinale var. Rubrum) Dan Lengkuas Merah (Alpinia Purpurata K. Schum) Terhadap Bakteri Patogen Dan Perusak Pangan. Bogor : Institut Pertanian Bogor.

13. Renny Agnesia, dkk. 2013. Aktivitas Antibakteri Fungi
Endofit Jahe Merah (Zingiber officinale var. rubrum) terhadap Escherichia coli dan

Streptococcus pyogenes.

Yogyakarta : Fakultas

Teknobiologi Universitas Atma Jaya.

14. Iñaki Lete and José Allué. 2016. The Effectiveness Of Ginger In The Prevention Of Nausea And Vomiting During Pregnancy And Chemotherapy (jurnal). Spain : Clinical Management Unit of Obstetrics and Gynecology, Hospital Universitario Araba, Vitoria, Spain. Plant Physiology Laboratory, Faculty of Biosciences, Universitat Autónoma de Barcelona, Bellatera, Spain.

15. Aspan Ruslan. 2008. Taksonomi Koloeksi Tanaman Obat Kebun Tanaman Obat Citeureup. Jakarta : Badan Pengawas Obat dan Makanan Republik Indonesia Deputi Bidang Pengawasan Obat Tradisional, Kosmetik, dan Produk Komplemen Direktorat Obat Asli Indonesia.

16. Ali Ghasemzadeh, et al. 2015. Optimization protocol for the extraction of 6-gingerol and 6shogaol from Zingiber officinale var. rubrum Theilade and improving antioxidant and anticancer activity using response surface methodology (jurnal). BMC Complementary and Alternative Medicine 
17. Hernani dan Christina Winarti. Kandungan Bahan Aktif Jahe Dan Pemanfaatannya Dalam Bidang Kesehatan. Bogor : Balai Besar Penelitian dan Pengembangan Pascapanen Pertanian

18. Rianto Setiabudy. 2013. Farmakologi dan Terapi. Jakarta : Balai Penerbit FKUI, Jakarta. Seksi VII. Hal 585,586,587

19. Siti Ngaisah. 2010. Identifikasi Dan Uji Aktivitas Antibakteri Minyak Atsiri Daun Sirih Merah (Piper Crocatum Ruiz \& Pav.) Asal Magelang (skripsi). Surakarta : Fakultas Matematika Dan Ilmu Pengetahuan Alam Universitas Sebelas Maret.

20. Ji Youn Lim1, Jang W. Yoon, and Carolyn J. Hovde1, 2013. A Brief Overview of Escherichia coli O157:H7 and Its Plasmid O15. J Microbiol Biotechnol

21. eLife. 2015. The Natural History Of Model Organisms The Unexhausted Potential of E. Coli in Blount. eLife 2015; 4:e05826. DOI: 10.7554/eLife.05826.

22. Jawetz, et al. 2012. Mikrobiologi Kedokteran edisi 25. EGC : Jakarta, hal 227, 228, 229

23. Setiati Sitti. 2014. Buku Ajar Ilmu Penyakit Dalam Jilid II. Jakarta : Publishing Interna
24. Clinical and Laboratory Standarts Institue. 2013. Disc Diffusion Suplemental Tables. 940 West Valley Road, Suite 1400, Wayne, PA 19607

25. Hendrianto Prasetyo. 2016. Uji Antibakteri Ekstrak Jahe Merah Zingiber Officinale Var. Rubrum terhadap Staphylococcus aureus dan Escherichia coli (jurnal). Surabaya : Akademi Farmasi Surabaya

26. Setiawan Wahyu. 2009. Aktivitas Antibakteri Ekstrak Etanol Batang Pepaya (Carica Papaya L) terhadap Staphylococcus aureus dan Escherichia coli Multiresisten Antibiotik (skripsi). Surakarta : Universitas Muhammadiyah Surakarta.

27. Cushnie, T.P. Tim., Lamb, A.J. 2005. Antimicrobial activity of flavonoids, Review Journal, www.pubmed.com/PMC 26 (2005) 343-356.

28. Indah Permata Sari,Kartika, dkk. 2013. Uji Antimikroba Ekstrak Segar Jahe-Jahean (Zingiberaceae) Terhadap Staphylococcus aureus, Escherichia coli dan Candida albicans (jurnal). Padang : Universitas Andalas.

29. Anna King. 2001. Quality assurance of antimicrobial susceptibility testing by disc diffusion. 